\title{
How to Recognize the Important Influence of Stravinsky's The Rite of Spring on Twentieth-Century Western Music and Modern and Contemporary World Music
}

\author{
Junxiang Liu \\ Queensland Conservatorium, Brisbane, Australia \\ Email:2728111377@qq.com
}

How to cite this paper: Liu, J. X. (2022). How to Recognize the Important Influence of Stravinsky's The Rite of Spring on Twentieth-Century Western Music and Modern and Contemporary World Music. Art and Design Review, 10, 103-119.

https://doi.org/10.4236/adr.2022.101008

Received: December 29, 2021

Accepted: February 13, 2022

Published: February 16, 2022

Copyright $\odot 2022$ by author(s) and Scientific Research Publishing Inc. This work is licensed under the Creative Commons Attribution International License (CC BY 4.0).

http://creativecommons.org/licenses/by/4.0/

\begin{abstract}
The Nationalist Period, the Neoclassical Period, and the Dodecaphony music (or Twelve Tone Music) Period are three important periods in the life of the Russian-born American music composer Stravinsky. The ballet The Rite of Spring, which was composed during the "Nationalist Period", has become a classic work in the history of music for its original composition, ingenious layout and bold innovative spirit, and has become an outstanding landmark work because of its uniqueness and exclusiveness. It also had a significant impact on twentieth-century Western music and contemporary world music. In order to analyse, explain, summarise and outline the "unique charm" and "artistic significance" of this epoch-making work of The Rite of Spring, this article has its focus on the following aspects such as the background of the composition, its musical features (harmony, orchestration, melody, structure, etc.) and its aesthetic characteristics.
\end{abstract}

\section{Keywords}

Stravinsky, The Rite of Spring, Historic Context, Musical Ontology, Aesthetic Characteristics

\section{Introduction}

Stravinsky's famous music work The Rite of Spring is regarded as one of the important compositions in the world. This music work contains the typical music features of "neoclassicism music" which had been appeared during the early $20^{\text {th }}$ century. Therefore, wishing to recognise "The Rite of Spring's" significant influence on $20^{\text {th }}$ century and contemporary modern music is a keen task to need 
to do. There are numerous scholarly dissertations or papers that are related to this music piece, but most of them lack systemic or complex research achievements. A few of them are lengthy and complicated; meanwhile, some of them are concise or short. In order to do an appropriate research job for the music work The Rite of Spring, a great deal of resources which are relevant to the relative academic works or journal articles have been studied. Those materials include Stravinsky's creative aesthetic thoughts, strategic conceptions and compositional skills for this unique music piece. This research project will focus on generating and refining what factors contribute to the particular success of Stravinsky's great music production The Rite of Spring in terms of the rhythm or meter, harmony, melody, instrumentation design and so on.

\section{Aims and Research Questions}

This research aims to develop a profound understanding of Stravinsky's music creation characteristics of The Rite of Spring and its significant impacts on the $20^{\text {th }}$ century and contemporary modern music. The concentration and the central task of the research are to investigate what factors contribute to the particular success of Stravinsky's musical compositions.

In order to design and conceive the whole paper, there is an overall research question which will be located at the centre of this investigative project. The specific question is: what factors contributed to the cultural and musical success of Stravinsky's piece The Rite of Spring?

Following items are four subsidiary issues which need to be responded concomitantly.

- What are the noteworthy characteristics in Stravinsky's musical compositions?

- Are there any relations between factors of musicology, history, ethnology (which are all included in ideology) and the musical specific work The Rite of Spring?

- Do the factors of particular rhythm, meter, melody, harmony, and instrumentation design and so on comprise the typical features to the music composition The Rite of Spring?

- Do Stravinsky's special growth experience and peculiar background of era have significant influences on his success of the musical production?

It is hoped that through this research Stravinsky's music creation features will be known by many scholars and other learners. A few methodologies or patters of investigation will be established to mass of the musical researchers or conveners. Such research achievements will be helpful to promote some composers' composition skills and to enrich musical study materials, and most importantly, to distinguish different styles of music from diverse eras such as eighteenth century, nineteenth century, and twentieth century.

\section{Literature Review and Theoretical Framework}

The concise overviews of relative literature and theoretical framework are of- 
fered by this part of the article. The overviews' goal is to describe and illustrate what musical compositional components which the music work The Rite of Spring has had been studied in previous academic research. What artistic impacts and factors had been summarized or outlined to the music work The Rite of Spring? There are still the knowledge gaps in the current scholarly resources. So trying to find how can examine or generate the relevant elements of the music work's compositional strategy is an important task to need to done.

The factors of musical history, aesthetics, and ethnology relate to The Rite of Spring.

There are the specific factors of history, aesthetics, and ethnology relating to the music work The Rite of Spring. Zhong (2019) states that the music composition of The Rite of Spring is one of the three important music works which had been composed by Stravinsky during his nationalism music phase. The "nationalism genre" had been arisen during the end of $19^{\text {th }}$ century and the early $20^{\text {th }}$ century in the worldwide. This "nationalism genre" usually uses folk melodies and rhythms, and selects the composer's own historical or realistic events as the theme for creation. Therefore, The Rite of Spring can be regarded as a typical nationalism music work since it contains distinctive characteristics of Russian folk music. So the musical ethnology factor can be seen clearly. In addition, Antokoletz (2014) explains that the beginning of the $20^{\text {th }}$ century was on the eve of the "First World War". This was a period of rapid development of large capitalist industries and social unrest. In this particular historical period, people's ideas had been innovated rapidly, and the needs of spiritual and cultural life had undergone major reforms. In the field of music creation, composers were eager to break the mode and shackles of late romantic music and create a new paradigm of music language and style. Therefore, Stravinsky's music production The Rite of Spring came into being. This is the historical factor of this work; furthermore, Statham (2010) illustrates in his articles that Stravinsky defines the type of The Rite of Spring as "ballet", this action can be regarded as ignoring or compounding that music work's problematic identity. This work had caused widespread controversy and debates in the field of musicology and performance. It is generally regarded as a milestone work of modern orchestral music and a work with significant divisive personality. From then, the aesthetic factors of The Rite of Spring might be understood fairly. All in all, it could be confirmed that there are factors of ethnology, history, and aesthetic relating to the music work The Rite of Spring.

The features of the particular melody, rhythm, harmony, structure form, and mode scales are also the important factors to the music work The Rite of Spring.

The main factors of The Rite of Spring are vital features of its melody, rhythm, harmony, structure form, and mode scales and so on. The varied music rhythm, multi tonal harmony and noisy and harsh sound effect are the outstanding impression and feeling of this work (Miller, 1991). Ruiz (2018) expands that there are discordant rhythms, chords and special intervals in this work. Woodruff (2006) also confirms that some sections of The Rite of Spring have the characte- 
ristics of "not subject to sequence constraints". The dynamic features of this dance drama are layered or multi rhythmic structure, irregular stress and span (Van den Toorn, 2017); at the melody aspect, Taruskin (1980) explains that the scattered and monotonous melody fragments in the work deepen the mystery of the primitive tribe in the work. The whole work is divided into two parts, and there is no coherent and specific plot, but only a few dance scenes (Zhong, 2019). It may be seen from the above descriptions that the features of the music form and its composition are the chief traits of The Rite of Spring.

The influences of Stravinsky's special growth experience and the particular background of era are on his success of the musical compositions.

Introduction to the composer and the context that the work is referred to.

Introduction to the composer.

Igor Fedorovich Stravinsky (1882-1971) was a world-renowned Russian-born American composer and conductor, as well as a typical representative of the "neo-classical music".

His musical works (listed below in chronological order) can be divided into three important periods: the nationalist period (or Russian style period), the neoclassical period, and the Dodecaphony, or the twelve-tone music period (Straus, 2001). Of these, the first period was his most successful.

Three dance dramas: The Firebird, Petrushka and The Rite of Spring are the most important masterpieces of Stravinsky's nationalist period. The Rite of Spring, which premiered in 1913, shocked the audience with its primitive, rough and deafening sound effects, and thus became a controversial work of the period and was rather rejected at first. Over time, however, the work eventually gained universal recognition and acclaim, and managed to become one of the jewels of the world's musical treasure house, enjoying the attention of the world.

Stravinsky was also known for his works during the neo-classical and twelve-tone periods. These include the dance drama Pulcinella (1920), the opera-oratorio Oedipus Rex (1927), the Symphony in C Major (1940), the opera The Rake's Progress (1951), the dance drama Agon (1957), the chorus Threni (1958) and the Requiem Canticles (1966) (Zhong, 2019). However, the composer's influence in the twelve-tone music period had waned considerably and new ideas had been lost, which highlighted the prominence and the reason for all the attention the work The Rite of Spring had got, in his creative career.

Stravinsky had great personal qualifications and endowments. His special family background and education (which is well known and will not be presented here) had forged a personality characterised by a wide range of knowledge and interests. He was highly skilled in the natural and social sciences as well as in fine art, especially painting. Some of the well-known figures in the Western literary community of the time, such as André Gide, Cocteau, and Romain Rolland were all his good friends (Boucourechliev \& Cooper, 1987). The musician Rimsky-Korsakov was one of his most important teachers. Autobiography (1935), Poetics of Music (1947) and Conversations with Stravinsky (1959) are his important written works (Zhong, 2019). It can thus be seen that Stravinsky was 
truly a brilliant and intellectually gifted musician.

In his "neo-classical period" Stravinsky advocated the idea of "going back to Bach". However, he focused only on the "structural elements" of Bach's music at the expense of its "emotional content". The aesthetic concept of establishing order and rules in a purely acoustic system and the pursuit of the "emotionlessness" of the expressive content of music (Zhong, 2019) is not dissimilar to the "sound without emotion" theory founded by Jikang, a musician in the Three Kingdoms period in ancient China. This is, to a certain extent, a reflection of Stravinsky's unique musical perspective and special aesthetic taste.

Background to the composition of the work.

The Rite of Spring was a ballet written by Stravinsky on commission from the head of the Russian Dance Company at the time, Serge Diaghilev. It was written in 1912 and premiered in 1913 at the Theatre des Champs-Elysees in Paris, France. It is well known that this time was on the eve of the First World War, a period of great industrial development and social unrest in Europe at the end of the nineteenth centuries and beginning of the twentieth centuries (Miller, 1991). The social anxiety, uncertainty, confusion and feeling of loss in the general public were reflected in the musical culture, which was characterised by a clear anti-conformity in the field of appreciation and creation. It was a time of constant innovation in the field of art, resulting in the emergence of new musical techniques and the coexistence of many musical styles. Some of the most creative musicians were keen to break the shackles of the late Romantic and Impressionist schools that dominated the musical scene. This was because the public's idolatrous worship of Wagner had led to a widespread atmosphere of foppishness in the music world. It was a pretense of elegance, a pretentious hypocrisy, a foolish old-fashioned style. This overly pretentious elegance and exaggerated glorification was at odds with the harsh social reality of the time, which often provoked feelings of panic and despair. Stravinsky therefore wanted to express his music with a sound that resembled the realities of nature. The famous French musician Oliver Messiaen once wrote (translated by Chinese scholars Zhang Huiling and Hong Ding): "As Stravinsky said in an interview with Le Monjuve about the composition of The Rite of Spring: 'In general, what I wanted to express in the Prelude was the commotion of nature in the revival of spring; the awe of the noonday sun; a feeling of reverence for the midday sun; a lament for Pan the pastoral god in Greek mythology. The initial musical material swells, develops and spreads. Each instrument is like a young shoot, breaking through the thick old bark to form an intimidating whole. And the orchestra had to show that everything was coming back to life in spring'." (Messiaen, 2012, p. 129-130). This interview transcript is Stravinsky's authentic monologue, a mapping of the origins of his aesthetic thinking in the creation of The Rite of Spring.

The call for research into systematic knowledge of the music work The Rite of Spring.

In order to fill the research gap of the systematic knowledge for the music work The Rite of Spring, many theory books or journal articles have been read. 
For example, the textbook of "harmony teaching" writes by Russian scholars Dubovsky et al. (2008); the books of "The analysis of musical compositions" write by Chinese scholars Li (2003) and Wu (1987) etc; the journal article "formalization of generative structure within Stravinsky's The Rite of Spring" writes by De Matteis \& Haus (1996) and "From The Firebird to The Rite of Spring. Meter and Alignment in Stravinsky's Russian-period works" writes by Van den Toorn (2013) and so on. Depending on all of these relevant theories, a systematic academic study would be carried out and got the expected outcomes.

\section{Research Method/Methodology}

There are highlighted similarities in the methodology employed by authors of above paragraphs. In this research paper, literature research method, case study method, Qualitative analysis method and function analysis method will be fully and appropriately applied.

Relation to "literature method", as above statement of "literature review" and "theoretical framework", there are too many scholarly acknowledge needing learning and studying. Therefore, extensive reading will be a suit way to broaden or expand one's horizon. For instance, in order to acknowledge the different musical periods' unlike music styles and genres, many historical documents need to be read and compared so as to learn more knowledge such as Grout (1996) describes in A History of Western Music as medieval church music, Baroque music, musical classicism, musical romanticism and musical modernism.

Relevance to "case study method", the main theme of the title of this research paper is that the principal research will be aimed to Stravinsky's specific musical composition The Rite of Spring. The definition of "case study" means focus on some specific themes. Since then, Stravinsky's special musical creation characteristics would be clearly interpreted and illustrated. So as to do a good job for this item, the action of information materials accumulation must be done, some materials include pictures, videos, audios or notes which are related to Stravinsky's life undergoing need to be accumulated just as Boucourechliev \& Cooper (1987) depicts.

About the "Qualitative analysis method", due to The Rite of Spring is a creative musical work, in order to recognize its compositional factors such as musical skills, conceptions, strategies and aesthetic tastes, researchers should focus on this musical work's particular "essence" and do a series of analysis job for it. The Stravinsky's specific musical works' scores should be analyzed, so that the peculiar characteristics of his musical works could be realized by most of the academic learners or students. The article which writes by Horlacher (2011) also uses analysis method to analyze The Rite of Spring. Therefore, this way could be used for reference to this research proposal. Only in this way, this research's final purpose would be reached and accomplished well.

In regard to the "function research method" (by formally analyzing the internal structural relationship of the phenomenon, we can clarify the formal ar- 
rangement and proportion of each element in the phenomenon), as Stravinsky's The Rite of Spring contributed an excellent work for the music world with its primitive conceiving, novel idea, delicate layout, and scene design. It is still considered a masterpiece and great example of innovative music almost a century late. So the musical composition's general aesthetic features could be regarded as the peculiar social function due to its significant influence in artistic field. This viewpoint might be confirmed by many scholars who are mentioned in this dissertation. The essay writes by Monteiro (2021) can also demonstrate this standpoint.

The special procedures are below.

At the beginning, the "case study method" and "literature method" which are to focus on the specific academic literature resources relating to the musical work The Rite of Spring had been used directly and sufficiently. Almost all of the valuable materials would be read carefully. Then, the "qualitative analysis method" had been used according researching on the music's main creative characteristics of The Rite of Spring. Next, the "function research method" had been utilized as a one way to attempt getting the aesthetic influence or impacts from many scholars or learners' theoretical articles.

\section{Findings/Results}

This project will fill the gap of knowledge which is about the realization for musician Stravinsky and his especial contributions to music at that particular historical phase. Stravinsky's music creation characteristic in his nationalism stage will be manifested since his important music work The Rite of Spring might be analyzed as an example with a specific essay. Stravinsky's another important musical work Firebird also has significant social influences from its generation (Roebuck, 1999). It is hoped that through relevant study of this project, the conspicuous music work The Rite of Spring's comprehensively extensive impacts on $20^{\text {th }}$ century and contemporary modern music could be identified.

In order to illustrate the pivotal results of the investigation, the detailed contents of the main body of the project will be showed as following:

An in-depth study of the work.

The definitional scope of the genres of "ballet" and "ballet-drama".

Ballet is a very elegant art genre in which the plot is profoundly interpreted through the rich body language of the dancers. Its graceful movements and subtle dance techniques allow for a perfect stage presence. The art of ballet is a wonder of the European cultural soil. It was originally conceived in Italy and later born in the French royal palace, so it has a long history of development. Because of its great elegance and significant influence, ballet has become a worldwide phenomenon and has been widely disseminated around the world (Crisp, 1978).

The dance drama is the main form of expression of the art of ballet. It com- 
bines music, art and dance in the same stage space, and through the close cooperation of the three arts, it creates an artistic effect of unity in time and space, as well as audio-visual unity.

The creative characteristics of the work.

Subject matter.

Myths and legends about the primitive pagan times in Russia, before the inflow of Christianity, are the subject matter of The Rite of Spring. The "Sacrificial Rites to the Earth", which was organised in spring by the ancient primitive peoples of Russia, is the main subject of this dance drama. The work is divided into two main sections: "Adoration of the Earth" and "The Sacrifice". The theme is that the beautiful maiden chosen in the "Mystical Circles of the Adolescent" would dance in front of the wise old men until she dies, in order to pray for the protection of her ancestors and to show her sincere reverence and gratitude to Mother Earth. Her "death" is the tribe's spring "sacrifice" to Mother Earth.

This subject matter reflects the primitivist element of the music of The Rite of Spring.

Rhythm and metre.

Breaking the limits of the bar line, of the regular alternation of intensity, and making the rhythm diverse and complex, is one of Stravinsky's most valuable innovations for this work (Zhong, 2019).

This feature is shown in score example 1 (reduced score for piano) from the section "Dances of the Adolescents".

Example 1:

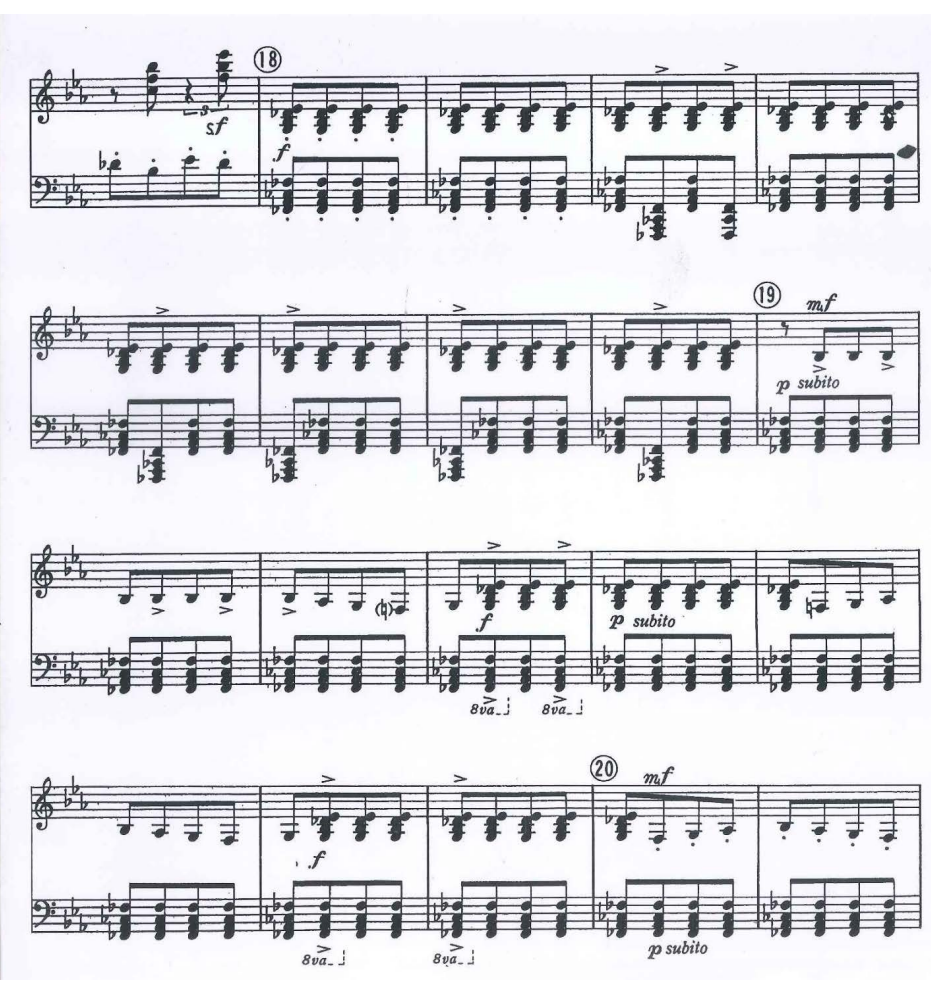


The accents in the score are mostly at different points of the beat, highlighting the rhythmic effect of "accent displacement". The atmosphere of panic, mystery and anger is expressed through the rhythmic conflict.

The rhythmic clashes are also evident in the second example 2 (reduced score for piano), also from the section "Dances of the Adolescents".

Example 2:

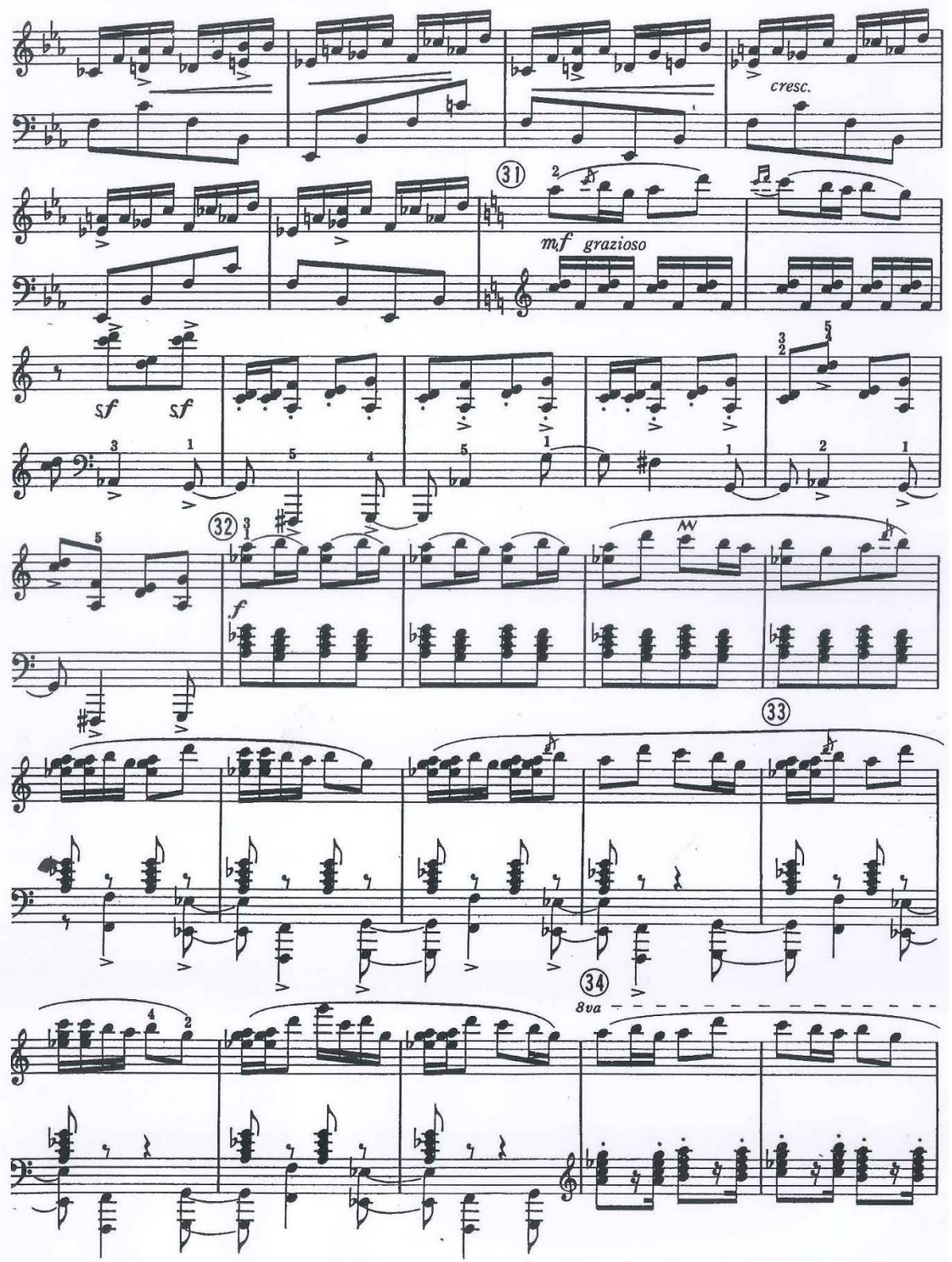

The changing accents and successive syncopations in this example give the music an unprecedented variety and dynamism, adding to the musical richness and subtlety of the dance.

Also, this is apparent in score example 3 (reduced score for piano) from the section "Glorification of the Victim".

Example 3: 

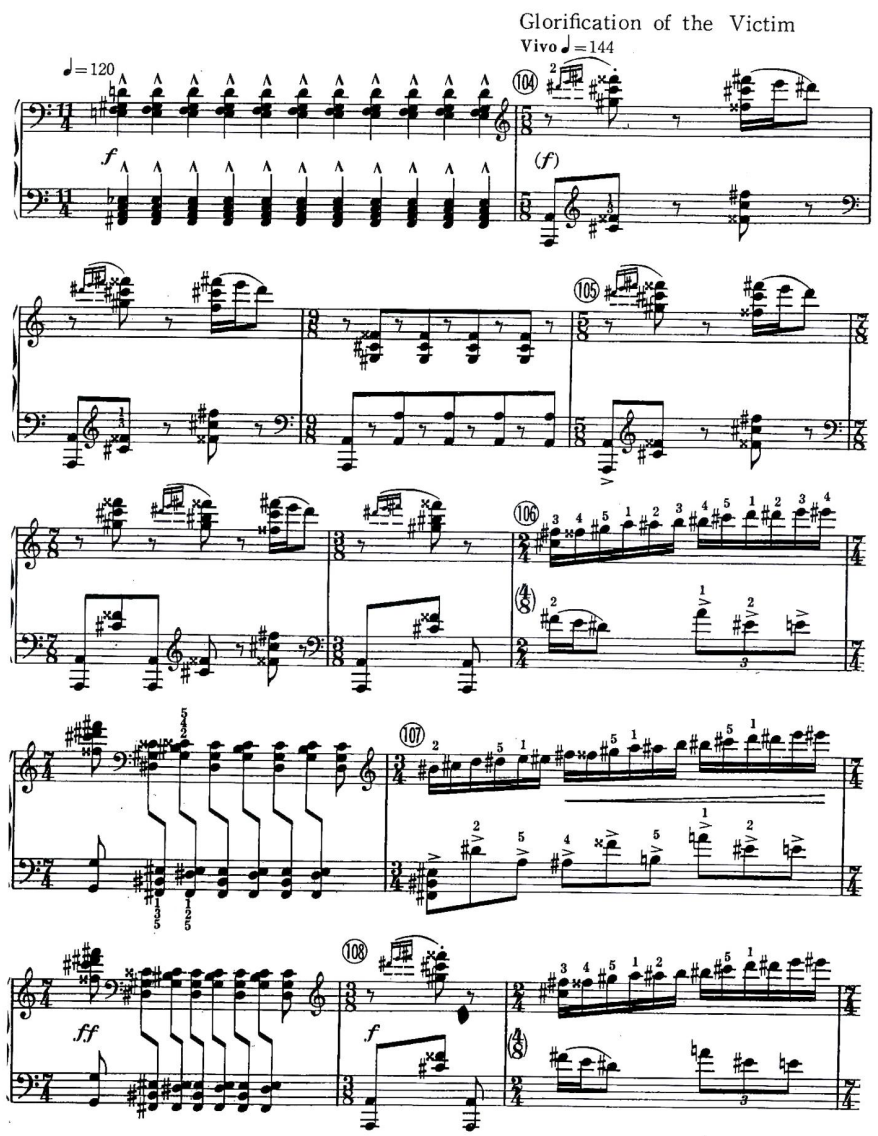

The number of beats in each bar of the score varies almost constantly, and the vertical compounding effect of the polyrhythms makes it possible to present the central meaning of each part of the music while maintaining the integrity of the work.

In short, the innovative use of rhythm and metre is a distinctive feature of the work. The whole work is thus dynamic and vibrant. It also makes Stravinsky's musical landscape particularly beautiful.

Harmony.

The use of dissonant chords, superimposed chords with non-three degree of intervals, and compound chords is a major harmonic feature of this work.

This is shown in score example 4 (reduced score for piano) from the section "Ritual of the Ancestors" (see the bars marked 129).

Example 4:

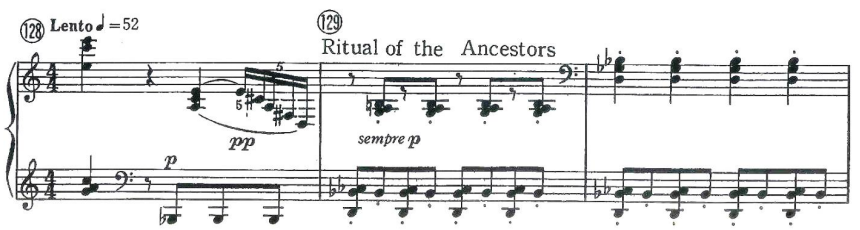

$\mathrm{D}$ to $\mathrm{bC}$ in the bass is a diminished seventh, so it forms a "diminished seventh chord". This is a dissonant chord and therefore has a sharp and strange acoustic 
effect.

This feature is also shown in score example 5 (reduced score for piano) from the section "Games of the Rival Tribes".

Example 5:

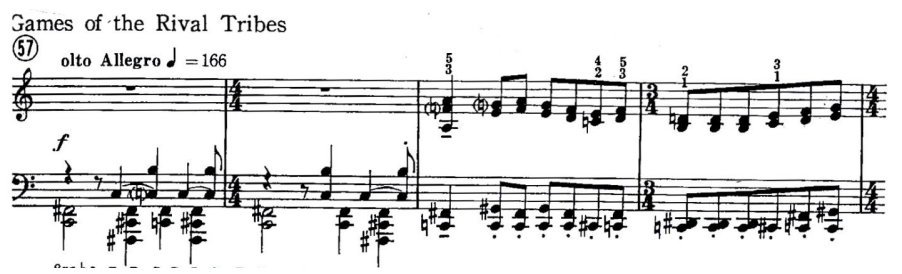

The chord in the bass part of the first two bars of this example is \#F B C (or B $\mathrm{C} \# \mathrm{~F})$. This chord is a non-third superimposed chord, which has the same effect as a dissonant chord.

The use of compound chords in this work can be seen in score example 6 (reduced score for piano) from the section "Mystical Circles of the Adolescent".

Example 6:

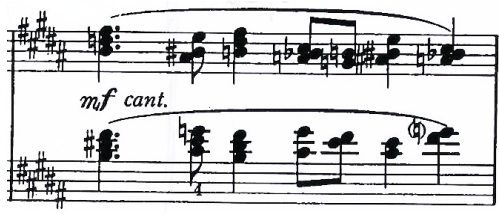

As we can clearly see from the first chord in the above example, the B \#D \#F in the bass is a major triad, while the $\mathrm{B} \mathrm{D} \# \mathrm{~F}$ in the treble is a minor triad, and the characteristics of the compound chord are evident.

The structure of the musical form.

The structure of the musical content of the various parts of The Rite of Spring is shown in the following table.

\begin{tabular}{|c|c|c|c|}
\hline \multirow{7}{*}{$\begin{array}{c}\text { Part One: } \\
\text { Adoration } \\
\text { of the Earth }\end{array}$} & Introduction & $0-12$ & Rondo form \\
\hline & Dances of the Adolescents & $13-36$ & Single one-part form \\
\hline & Mock Abduction & $37-47$ & Single one-part form \\
\hline & Spring Rounds & $48-56$ & Single ternary form \\
\hline & Games of the Rival Tribes & $57-65$ & Compound two-part form \\
\hline & Procession of the Sage & $66-71$ & Single one-part form \\
\hline & Dance of the Earth & $72-78$ & Single ternary form \\
\hline \multirow{6}{*}{$\begin{array}{l}\text { Part two: } \\
\text { The Sacrifice }\end{array}$} & Introduction & $79-90$ & Single two-part form \\
\hline & Mystical Circles of the Adolescent & $91-103$ & Single ternary form \\
\hline & Glorification of the Victim & $104-120$ & Single ternary form \\
\hline & Evocation of the Ancestors & $121-128$ & Single one-part form \\
\hline & Ritual of the Ancestors & $129-141$ & Compound ternary form \\
\hline & Sacred Dance-The Victim & $142-201$ & Rondo form \\
\hline
\end{tabular}


As can be seen from the above table, The Rite of Spring is a large orchestral work in the nature of a multi-part "suite".

Melody.

The use of sporadic and scattered melodic breaks, short melodic fragments and monotonous cycles of these melodic fragments, and the use of melody as a rhythmic phrase are prominent features of the use of "melody" in this work.

The full melodic line played by the oboe in the upper register at the beginning of the piece foreshadows the typical Russian folk music tone of the entire work. The melody sounds bizarre and grotesque but is exceptionally beautiful. Together with the other parts of the melody, it forms a special musical mood and atmosphere of either sorrow and pathos, horror and carnage, tranquillity and distance, or boisterousness, which effectively brings out the image of the Russian primitive people as a bold and pious publics, and demonstrates their humanistic feelings of gratitude to the earth and nature.

This new form of musical expression is a challenge and a rebellion against the traditional "high voice melodic" style and heralds the direction of new music in the twentieth century. Its exemplary effect was a driving force in the development of modern music.

Orchestration.

Please refer to the following score example 7 (full orchestral score).

Score Example 7

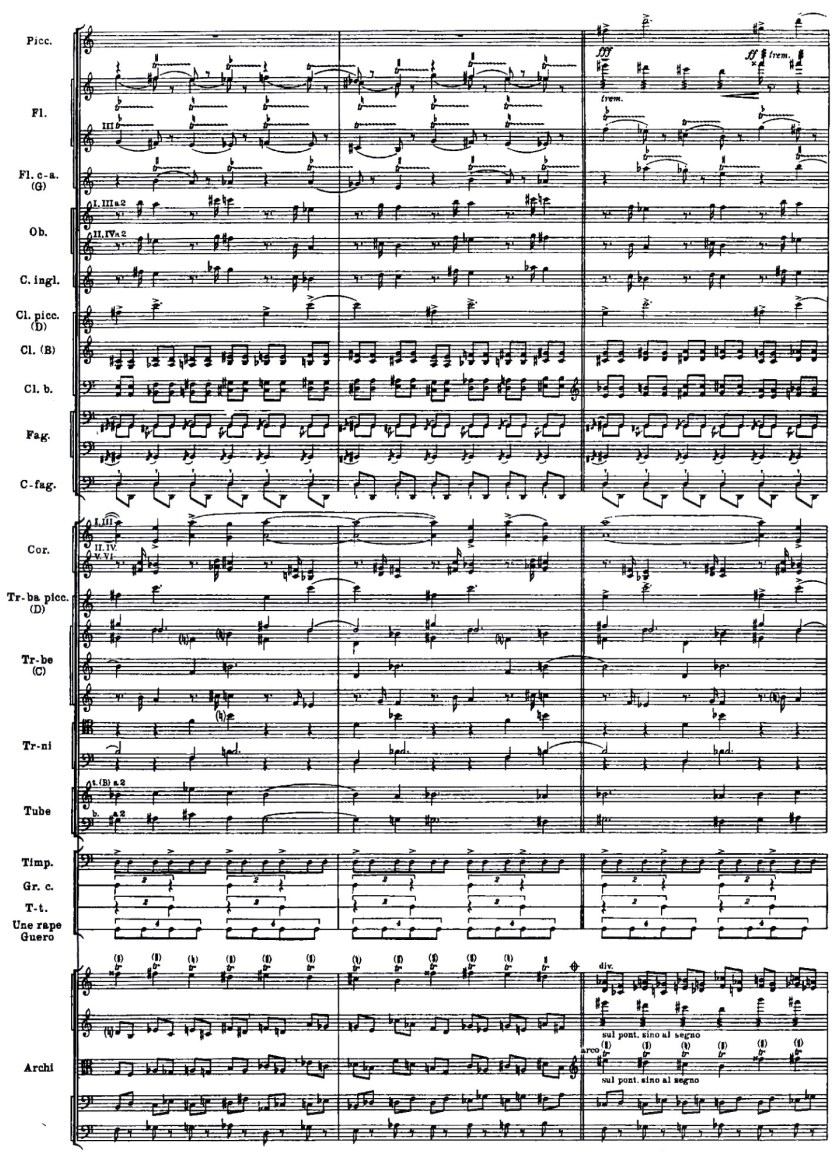


The orchestra formation of The Rite of Spring can be seen at a glance in the instrumentation column on the left-hand side of this full orchestral score. This is a large orchestra, and Stravinsky's unique orchestration reflects his particular aesthetic vision and musical taste. The specific orchestration of this work is characterised by the five features listed as follows.

Chamber music orchestration.

The orchestration of most passages of the work is woven with a few instruments of various types, with only about $1 / 5$ of the sections featuring the full orchestra (e.g. the full orchestra fragments in the Dances of the Adolescents, the Spring Rounds and the Evocation of the Ancestors) (Wu, 2004). This chamber orchestration allows the rhythmic and tonal contrasts of the various sections of the orchestra to be effectively enhanced, thus further emphasising the rhythmic character of the work.

Experimentation with the special timbre of conventional instruments.

The deeper tones of the bass clarinet, the lower clarinet and the soprano of the oboe are particularly favoured by the composer (Messiaen, 2012) in order to create a primitive, empty and desolate musical mood. These special timbres, woven together with the other timbres, build up the work's bizarre and grotesque acoustic edifice.

The innovation of the technique of playing string instruments.

In The Rite of Spring, the stringed instruments have been revolutionised in an unprecedented way. Vibrato, overtones, plucking, playing close to the yard, con sord, bowing and other special techniques are used extensively. The bizarre acoustics of these new techniques are an integral part of the strange and wild soundscape of this work.

See the following score example:

Score Example 8

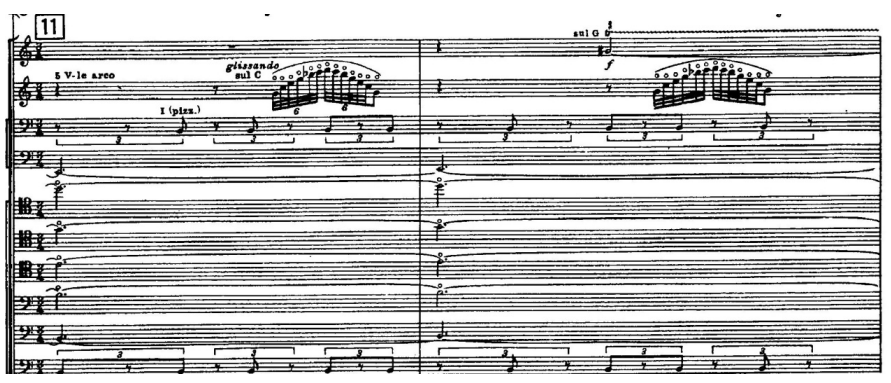

Score Example 9

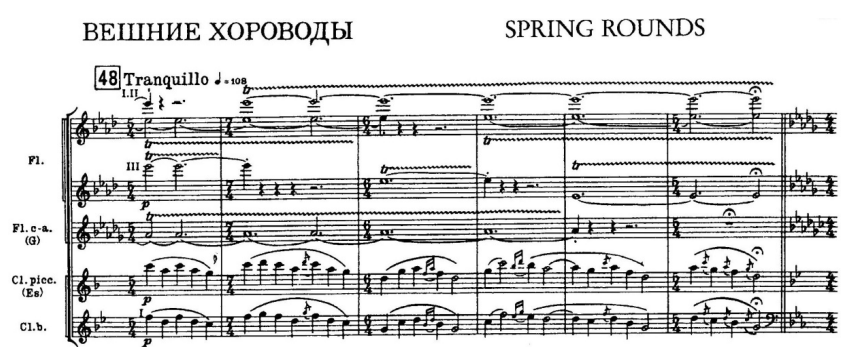


Score Example 10

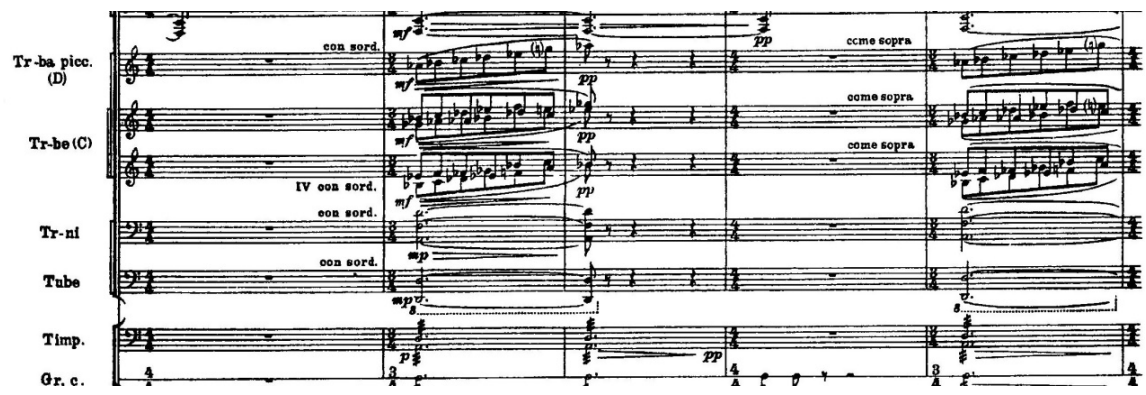

Score Example 11

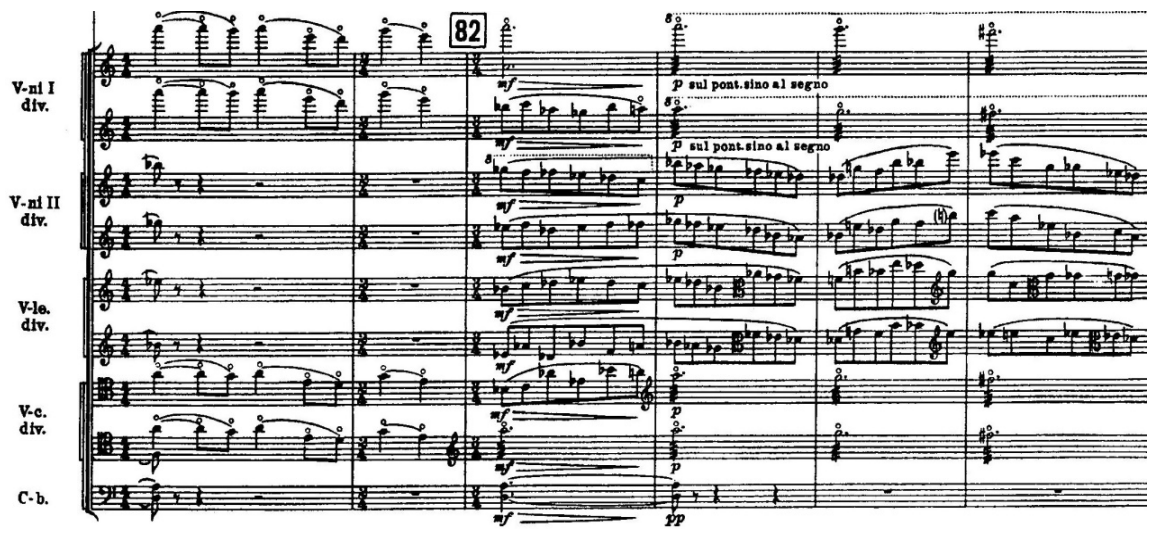

The use of trembolo, trill, glissando and other special techniques is effective. See score example as below showing: Score Example 12

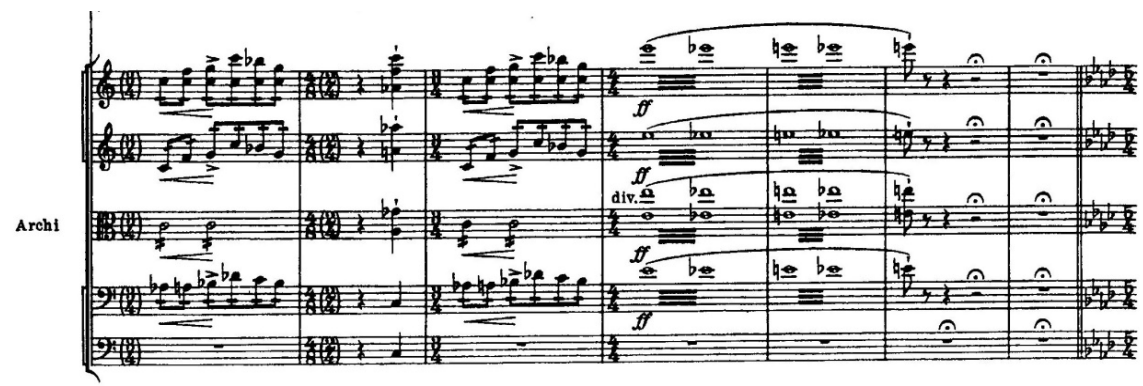

Score Example 13

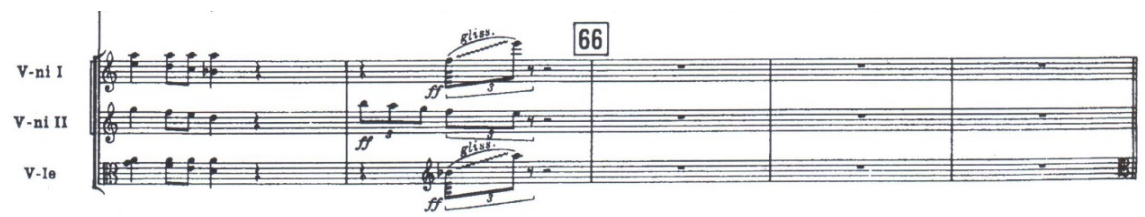

Score Example 14 


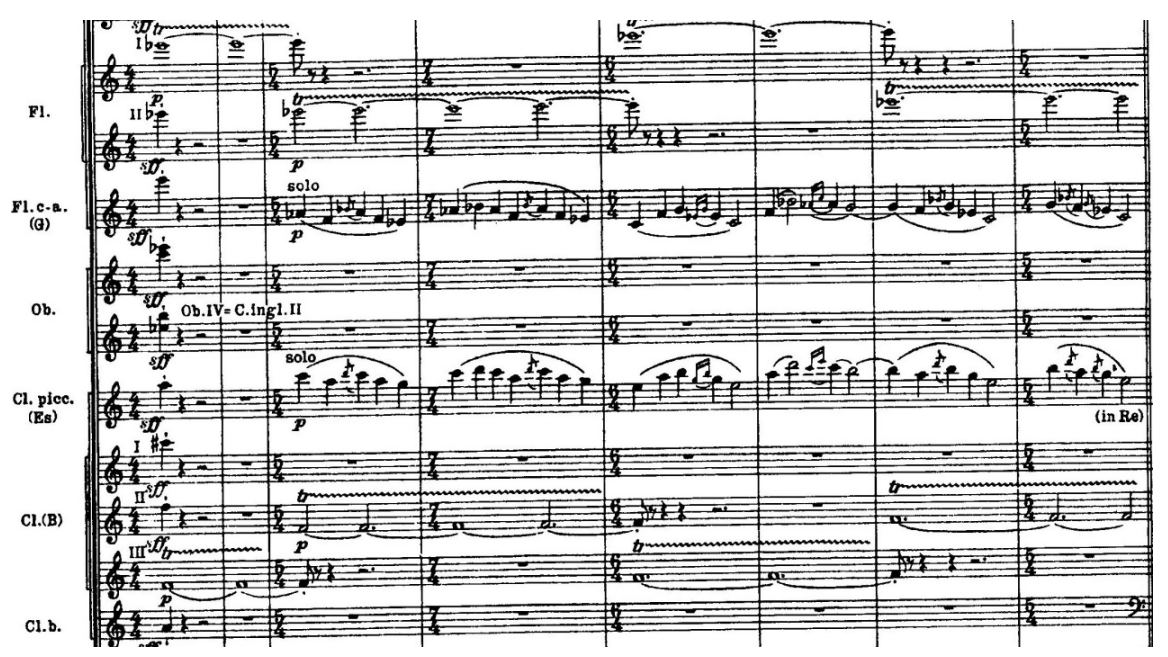

The use of colourful percussion instruments. Gr.c, T-t, Une rape, Guero, etc. The artistic value and significance of The Rite of Spring in the music history.

In the early twentieth century, when many musical genres and styles co-existed, Stravinsky's ballet The Rite of Spring was a thunderbolt that shook the music world to its core. Audiences and music critics alike were first dumbfounded and dazzled, and then overwhelmed by the primitivism and Russian folk music charm of the work. This artistic spirit of taking inspiration from nature and folk music, this subordination of "musical form" to "musical content" in order to express the "irrational" and "uncultured" savagery of a prehistoric people, is a revolutionary approach. The spirit of innovation, the spirit of breaking through the shackles of traditional music and the spirit of seeking to be unique, has brought useful enlightenment to the majority of music creators and has given a strong impetus to the development of music history.

This work is therefore of epoch-making significance in the history of music. It is unanimously regarded by scholars as a "pivotal" work linking "tradition" and "modernity", a classic "milestone" work, and a "landmark" work.

\section{Discussion}

This research paper synthetically presents the prominent music work The Rite of Spring's creation characteristics and musical connotations from different aspects. The main contribution of the research is to analyze the musical work itself and summarize the composition's particular conceiving ideas, unique styles and comprising structures. All of these components rendering the musical work's creative features, theoretical inheritance and delicate concepts are absolutely and obviously illustrated.

From the above finding sections, it can be clearly seen that the definitional scope of the genres of "ballet" and "ballet-drama"; The music work The Rite of Spring's specific creative characteristics such as subject matter; breaking the limits of the bar line's regular alternation and the changing accents and successive syncopations of rhythm and metre; the use of dissonant chords and other pecu- 
liar chords of harmony; the particular structure of the musical form; the utilization of sporadic, scattered melodic breaks, and short melodic fragments; Vibrato, overtones, plucking, playing close to the yard, bowing and other special techniques of the stringed instruments are extensively used and so on.

Among all of the aspects, two factors of the relationship between music and ideology (which relate to music aesthetic, music history, and music ethnology) and the link between music and its form or comprising (which involve harmony, melody, structure, and other technique forms) could be clearly known.

As it also might be known in this music work' compositional ways that a large orchestral work could be in the nature of a multi-part "suite". In addition, superimposed chords, compound chords, instrumentation or melody features and other aspects are very beneficial to many music composers to referring and learning.

Moreover, most readers and music learners will be able to gain a whole or entire recognition to the music work The Rite of Spring. Such condition will be beneficial to the systemic study of Stravinsky's most musical compositions.

\section{Conclusion}

Stravinsky's ballet The Rite of Spring is a work of both "creative" and "aesthetic" value. In this work, the composer's personal ingenuity and ingeniousness are fully reflected in the choice of material, harmonic structure, melodic development, instrumental arrangement, rhythmic innovation, metrical design and overall structure. The result is a work of unique style that, despite its controversial beginnings, has been a lasting and luminous success. It has become a professional concert classic and has gained worldwide popularity.

In this work, Stravinsky's "rebellious" musical language proclaims the independence of his personality and his "anti-traditional" thoroughness. It reflects the qualities of an outstanding composer who valued "music from the heart" and the expression of his innermost feelings, as well as his innovative spirit of exploration and his bold and wise humanistic qualities in response to the times.

It would be known apparently from this music work, the relation between music and musical ideology (such as musicological aesthetic, history and ethnology); the link between music and musical forms or constitutions (such as music rhythm, metre, melody, harmony, structure and scales and so on) is sufficiently explained.

\section{Conflicts of Interest}

The author declares no conflicts of interest regarding the publication of this paper.

\section{References}

Antokoletz, E. (2014). A History of Twentieth-Century Music in a Theoretic-Analytical Context. Routledge.

Boucourechliev, A., \& Cooper, M. (1987). Stravinsky. Victor Gollancz Ltd. 
Crisp, C. (1978). Ballet Art: From the Renaissance to the Present. Crown Publishers.

De Matteis, A., \& Haus, G. (1996). Formalization of Generative Structures within Stravinsky's “The Rite of Spring”. Journal of New Music Research, 25, 47-76. http://doi.org/10.1080/09298219608570697

Dubovsky, Y., Yepsyev, S., Sposobin, Y., \& Sokolov, F. (2008). Harmonics Course. People's Music Publishing House.

Grout, D. J. (1996). A History of Western Music (5th ed.). W.W. Norton.

Horlacher, G. G. (2011). Building Blocks: Repetition and Continuity in the Music of Stravinsky. Oxford University Press.

Li, J. T. (2003). The Analysis of Musical Compositions. Central University for Nationalities Press.

Messiaen, O. (2012). An Analysis of Stravinsky's Sacrifice of Spring (Part I) (Zhang, H. L., \& Hong, D., Trans.). Journal of the Central Conservatory of Music, 3, 129-130. http://www.ccom.edu.cn/xwyhd/zxdt/2017s/201704/t20170407_42853.html

Miller, H. M. (1991). History of Western Music (5th ed.). Harper Perennial.

Monteiro, A. C. (2021). Dissociation between Harmonic Form and Structure in Works by Claude Debussy and Igor Stravinsky. Universidade Federal de Goiás, 21, 30.

Roebuck, E. (1999). Stravinsky's Firebird and Young Children. Music Educators Journal, 86, 34-52. https://griffith-summon-serialssolutions-com.libraryproxy.griffith.edu.au

Ruiz, M. J. (2018). Clash of Harmonics in Stravinsky's “The Rite of Spring”. The Physics Teacher, 56, 218-221. http://doi.org/10.1119/1.5028234

Statham, S. (2010). Igor Stravinsky. The Rite of Spring. Henrik Schaefer. Music Library Assoc, 66, 626-627.

https://griffith-summon-serialssolutions-com.libraryproxy.griffith.edu.au

Straus, J. N. (2001). Stravinsky’s Late Music. Cambridge University Press.

Taruskin, R. (1980). Russian Folk Melodies in “The Rite of Spring”. Journal of the American Musicological Society, 33, 501-543. http://doi.org/10.1525/jams.1980.33.3.03a00040

Van den Toorn, P. C. (2013). From the Firebird to "The Rite of Spring": Meter and Alignment in Stravinsky's Russian-Period Works. Avant, 4, 45-65.

Van den Toorn, P. C. (2017). The Rite of Spring Briefly Revisited: Thoughts on Stravinsky's Stratifications, the Psychology of Meter and African Polyrhythm. Music Theory Spectrum, 39, 158-181. http://doi.org/10.1093/mts/mtx015

Woodruff, E. G. (2006). Metrical Phase Shifts in Stravinsky's the Rite of Spring. Music Theory Online, 12. http://doi.org/10.30535/mto.12.1.1

Wu, S.W. (2004). A Study on the Rhythm of the Rite of Spring and Its Influence, Development and Variation in Western Modern Music Creation-Also on the Influence on Chinese Modern Music Creation. Baidu Wenku.

Wu, Z. Q. (1987). The Analysis of Musical Compositions. People's Music Publishing House.

Zhong, Z. L. (2019). Overview of Western Modern Music. People's Music Publishing House. 